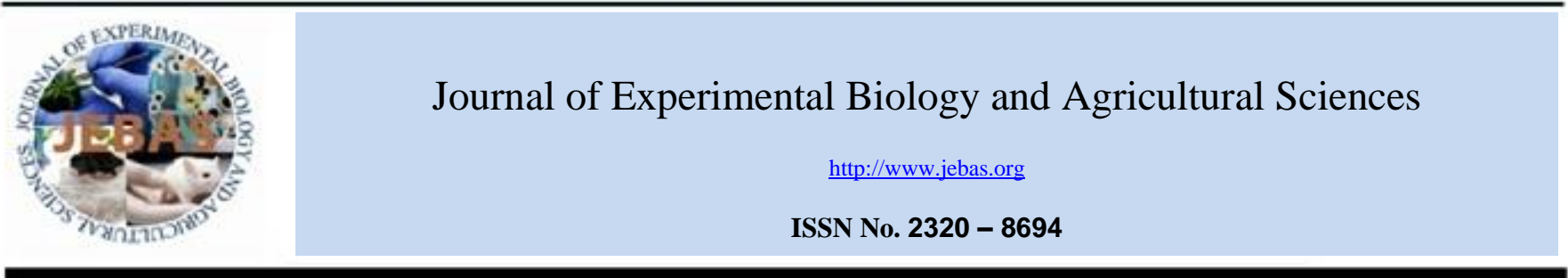

\title{
FIRST REPORT OF FUNCTIONAL IDENTIFICATION OF MUSCARINIC RECEPTORSIN THE SMALL INTESTINE OF JAPANESE QUAIL (Coturnix coturnix japonica)
}

\author{
B. M. Sanjay ${ }^{1}$, Suresh N. Nair ${ }^{2}$, Sanis Juliet ${ }^{1}$, M. Megha ${ }^{1}$, M. S. Shijin ${ }^{1}$, S.V. Suraj ${ }^{1}$, \\ C. Ravisankar ${ }^{3}$, A.R.Nisha ${ }^{2}$, K.G. Ajithkumar ${ }^{4}$

\begin{abstract}
${ }^{1}$ Department of Veterinary Pharmacology and Toxicology, College of Veterinary and Animal Sciences, Pookode, Wayanad, Kerala- 673576
${ }^{2}$ Department of Veterinary Pharmacology and Toxicology, College of Veterinary and Animal Sciences, Mannuthy, Thrissur, Kerala- 680651

${ }^{3}$ Department of Veterinary Microbiology, College of Veterinary and Animal Sciences, Pookode, Wayanad, Kerala- 673576

${ }^{4}$ Department of Veterinary Parasitology, College of Veterinary and Animal Sciences, Pookode, Wayanad, Kerala- 673576
\end{abstract}

Received - December 25, 2019; Revision - February 03, 2020; Accepted - February 24, 2020

Available Online - February 25, 2020

DOI: http://dx.doi.org/10.18006/2020.8(1).71.75

\author{
KEYWORDS \\ Quail \\ Muscarinic receptors \\ EC50 \\ $\mathrm{pD} 2$ \\ Ileum
}

* Corresponding author

E-mail: suresh@kvasu.ac.in (Dr Suresh N Nair)

Peer review under responsibility of Journal of Experimental Biology and Agricultural Sciences.

Production and Hosting by Horizon Publisher India [HPI] (http://www.horizonpublisherindia.in/).

All rights reserved.

\begin{abstract}
Motility of small intestine which determines the efficacy of digestion and assimilation of nutrients and thus the rate of growth in the animals and birds is modulated mainly by muscarinic cholinergic receptor system. The efficacy of agonists and antagonists in modulating the gastrointestinal motility is governed by subtypes of muscarinic receptors present in the organs. So far, there are no reports of muscarinic receptors of quail intestine. Hence the current study was conducted for identifying the muscarinic receptor subtypes for better pharmacological management of dysfunctions of the small intestine of Japanese quail. Eight healthy quails of either sex were raised under uniform management conditions. Birds were euthanized and two to three centimetres length ileum was separated from a region five centimetres away from the ileo-caecal junction and transferred to Tyrode solution at $37.2{ }^{\circ} \mathrm{C}$. The ileum tissue was mounted under $1 \mathrm{~g}$ tension in an organ bath chamber with constant aeration. The contractile responses to the agonist alone, agonist in presence of antagonists and relaxant effect of muscarinic receptor antagonists with submaximal contraction of ACh were recorded with isometric transducer connected to a recorder. The median effective concentration 50 (EC50) and pD2 values were determined. From the results it is evident that muscarinic acetylcholine receptors are present in the ileum of Japanese quail which, as per our knowledge is the first report of this receptor in Japanese quail intestine. The EC50 values of acetylcholine alone in ileum of Japanese quail varied from $1.235 \times 10^{-7} \mathrm{M}$
\end{abstract}


value of $1.701 \times 10^{-7} \mathrm{M}$ and $\mathrm{pD} 2$ value of 6.769.It was also confirmed that Tyrode solution is better suited for assessment of intestinal motility of quail. This model can be useful as a cheap and effective replacement for rat intestinal experiments.

\section{Introduction}

The history of cholinergic receptors start with the experiments performed independently by Henry Dale and Otto Loewi, whose spectacular works identified the neurotransmitter acetylcholine that is responsible for vasodepressor effects on frog heart preparation (Dale, 1914; Loewi, 1921). The muscarinic acetylcholine receptors are $\mathrm{G}$ protein coupled receptors with seven transmembranespanning domain acting through second messengers (Bonner et al., 1987; Alexander et al., 2017). There are five different subtypes of muscarinic receptors namely $\mathrm{M}_{1}, \mathrm{M}_{2}, \mathrm{M}_{3}, \mathrm{M}_{4}$ and $\mathrm{M}_{5}$ which are pharmacologically different based on the competition between antagonists and agonists (Gholamnezhad et al., 2018).The oddnumbered muscarinic acetylcholine receptors i.e. $\mathrm{M}_{1}, \mathrm{M}_{3}$ and $\mathrm{M}_{5}$ receptors caused the activation of phospholipase $\mathrm{C}$, generating two secondary messengers inositol 1, 4, 5-trisphosphate $\left(\mathrm{IP}_{3}\right)$ and diacylglycerol (DAG) eventually leading to an intracellular increase of calcium, while the even-numbered muscarinic acetylcholine receptors vi., $\mathrm{M}_{2}$ and $\mathrm{M}_{4}$ inhibit adenylatecyclase, thereby decreasing the production of the second messenger cyclic adenosine monophosphate (cAMP). Muscarinic receptors play an important role in the motility of gastrointestinal tract; their presence was reported in small intestine of most of the livestock and chicken (Delvalle et al., 2018). But, so far, there are no reports of cholinergic receptor response and their subtypes present in the small intestine of Japanese quail. Hence the current study was conducted to assess functional activity of cholinergic system by finding the median effective concentration (EC50) of acetylcholine (Ach) in the ileum of Japanese quail.

\section{Material and Methods}

\subsection{Preparation of quail ileum for isolated organ bath experiment}

Eight healthy three to six months old Japanese quail (Coturnix coturnix japonica) weighing 110-120 g were procured from Kozhikode district, Kerala, India and maintained three weeks for acclimatization under standard uniform managemental conditions. All the experiments involving quails and quail tissues were reviewed and approved by the Institutional Animal Ethics Committee (IAEC/COVAS/PKD/3/2019) and conformed to the CPCSEA guidelines. The birds were euthanized by anaesthetic overdose and two to three centimetres length ileum was separated from a region five centimetres away from the ileo-caecal junction and was transferred to Tyrode solution kept at $37.2{ }^{\circ} \mathrm{C}$. The lumen and surface of ileum was washed and flushed with Tyrode solution. The fascia adhering to the tissue were carefully removed and one end of the ileum was fixed to tissue holder which was then mounted in to the tissue chamber of organ bath containing $20 \mathrm{ml}$ Tyrode solution and the other end of ileum was tied to an isometric force transducer. The bath temperature was maintained at $37.2{ }^{\circ} \mathrm{C}$ and constantly aerated with atmospheric airtill the end of the experiment. The tension was recorded using a polygraph digital data acquisition system linked to isometric force transducer connected to a recorder (M/s INCO, India). The ileum was mounted under $1 \mathrm{~g}$ resting tension and allowed to equilibrate for 60 minutes before the commencement of the experiment. During the equilibration period of 60 minutes, Tyrode solution was changed every 15 minutes. The contractile response to the agonist acetylcholine was recorded with isometric transducer connected to a recorder (Apu et al., 2016). The composition of Tyrods solution was as follows: $137 \mathrm{mM}$ sodium chloride $(\mathrm{NaCl}) ; 2.7 \mathrm{mM}$ potassium chloride $(\mathrm{KCl}) ; 1.8 \mathrm{mM}$ calcium chloride $\left(\mathrm{CaCl}_{2}\right)$; $0.5 \mathrm{mM}$ magnesium chloride $\left(\mathrm{MgCl}_{2}\right) ; 11.9 \mathrm{mM}$ sodium bicarbonate $\left(\mathrm{NaHCO}_{3}\right) ; 0.4 \mathrm{mM}$ sodium dihydrogen phosphate $\left(\mathrm{NaH}_{2} \mathrm{PO}_{4}\right)$; and $5.55 \mathrm{mM}$ glucose. The ileum tissue was mounted under $1 \mathrm{~g}$ constant resting tension and allowed to equilibrate for 60 minutes before commencing the experiment, changing the solution every 15 minutes (Ghosh, 2014).

\subsection{Dose- response curve of acetylcholine}

A dose response curve was constructed by adding successive cumulative concentrations of $\mathrm{ACh}$ ranging from $10^{-7} \mathrm{M}$ to $10^{-2} \mathrm{M}$, the procedure was repeated after giving 30 minutes rest for the tissue and same is followed for remaining quails to get the uniform responses (Ghosh, 2014).

\subsection{Assessment of functional response of quail ileum to acetylcholine}

Contractile responses to $\mathrm{ACh}$ in quail ileum were converted to percentage and the graph was plotted against the logarithmic concentration of ACh. The effective concentration (EC50) and pD2 value were calculated by non-linear regression analysis using GraphPad Prism (Ver.5.0.)

\section{Results}

The present study was conducted to find the median effective concentration (EC50) of ACh in ileum of Japanese quail. 


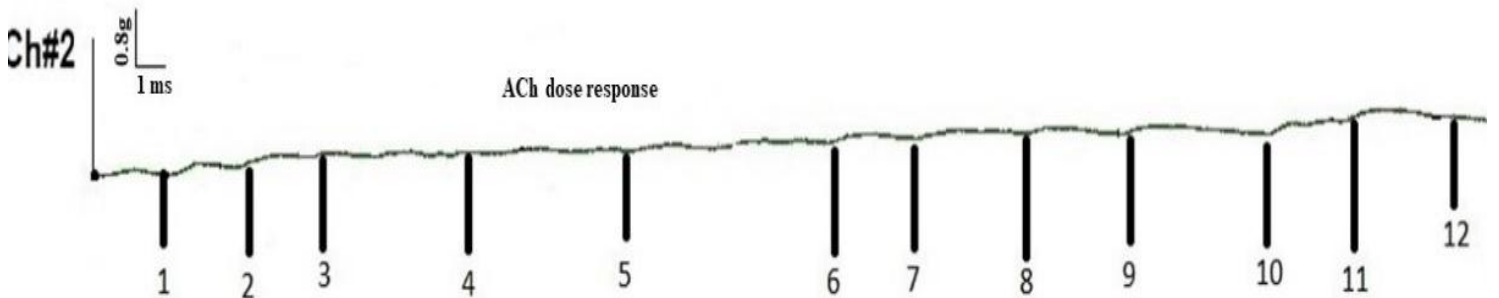

Figure 1: Representative physiographic recording of contractile effect of $\mathrm{ACh}$ on quail ileum. The numbers on the graph indicate the cumulative doses as given belowDose $1=0.5 \times 10^{-9} \mathrm{M}$; Dose $2=1.5 \times 10^{-9} \mathrm{M}$; Dose $3=0.5 \times 10^{-8} \mathrm{M}$; Dose $4=1.5 \times 10^{-8} \mathrm{M}$; Dose $5=0.5 \times 10^{-7} \mathrm{M}$; Dose $6=1.5 \times 10^{-7} \mathrm{M}$; Dose $7=0.5 \times 10^{-6} \mathrm{M}$; Dose $8=1.5 \times 10^{-6} \mathrm{M}$; Dose $9=0.5 \times 10^{-5} \mathrm{M}$; Dose $10=1.5 \times 10^{-5} \mathrm{M}$ Dose $11=0.5 \times 10^{-4} \mathrm{M}$; Dose $12=1.5 \times 10^{-4} \mathrm{M}$

Representative physiographic recording of cumulative dose response curve of acetylcholine is represented in Figure 1. Mean cumulative graded dose response in given the table 1. The EC50 value of ACh varied from $1.235 \times 10^{-7}$ to $2.344 \times 10^{-7}$ with mean value of 1.701 X $10^{-7}$ at $95 \%$ confidence interval (Table 2). The mean $\mathrm{pD} 2$ value of quail ileum for acetylcholine was $6.78 \pm 0.08$ (Table 3). The cumulative log dose response curve is depicted in Figure 2.

\section{Discussion and conclusion}

From the results it is evident that muscarinic acetylcholine receptors are present in the ileum of Japanese quail which, as per our knowledge is the first report of muscarinic receptor in Japanese Quail intestine. The EC50 values of acetylcholine alone in ileum of Japanese quail varied from $1.235 \times 10-7 \mathrm{M}$ to $2.344 \mathrm{X} 10-7 \mathrm{M}$ with mean value of $1.701 \mathrm{X} 10-7$ $\mathrm{M}$ and $\mathrm{pD} 2$ value of 6.769 . Since there are no reports of muscarinic receptors in quail, comparison was made with the chicken ileum, where the mean EC50 and $\mathrm{pD} 2$ values of carbachol, another muscarinic receptor agonist was reported to be $3.54 \times 10^{-6} \mathrm{M}$ and 5.45 with (Darroch et al., 2000). The mean EC50 and pD2 values of acetylcholine were $1.94 \times 10^{-7} \mathrm{M}$ and 6.71 and for carbachol, the mean EC50 and pD2 values were $5.12 \times 10^{-8} \mathrm{M}$ and 7.29 in chicken proventriculus (Kitazawa et al., 2016). This results conforms to the present findings in quail. In other species of animals the mean EC50 and pD2 values were $1.23 \times 10^{-6} \mathrm{M}$ and 5.91 in ileum, $9.77 \times 10^{-7} \mathrm{M}$ and 6.01 in trachea and $7.24 \times 10^{-7} \mathrm{M}$ and 6.14 in oesophageal muscularis mucosa for pilocarpine (guinea pig). The mean EC50 and pD2 values were $1.86 \times 10^{-7} \mathrm{M}$ and 6.73 in ileum, $2.54 \times 10^{-7} \mathrm{M}$ and 6.61 in trachea and $1.54 \times 10^{-7} \mathrm{M}$ and 6.81 in
Table 1 Mean percent contraction of quail ileum with respect to log dose of Ach ( $\mathrm{n}=6$ )

\section{Acetylcholine Conc. [Log M]}

$\%$ Contractile response

\begin{tabular}{|cc|}
\hline-9.30103 & 0 \\
\hline-8.823909 & $12.49 \pm 0.91$ \\
\hline-8.30103 & $22.43 \pm 0.89$ \\
\hline-7.823909 & $33.66 \pm 1.51$ \\
\hline-7.30103 & $43.93 \pm 1.92$ \\
\hline-6.823909 & $53.75 \pm 1.88$ \\
\hline-6.30103 & $64.57 \pm 1.31$ \\
\hline-5.823909 & $76.38 \pm 1.49$ \\
\hline-5.30103 & $89.96 \pm 0.56$ \\
\hline-4.823909 & 100 \\
\hline-4.30103 & 100 \\
\hline-3.823909 & 100 \\
\hline
\end{tabular}

Table 2 EC50 of ACh on ileum of Japanese quail

\begin{tabular}{|cc|}
\hline Parameters & Mean \\
\hline LogEC50 & $-6.769 \pm 0.06974$ \\
\hline EC50 & $1.701 \times 10^{-7}$ \\
\hline \multicolumn{2}{|c|}{$95 \%$ Confidence Intervals } \\
\hline LogEC50 & -6.908 to -6.630 \\
\hline EC50 & $1.235 \times 10^{-7}$ to $2.344 \times 10^{-7}$ \\
\hline
\end{tabular}

Table $3 \mathrm{pD} 2$ values of ACh with mean $\pm \mathrm{SE}$

\begin{tabular}{cccccc|cc|} 
& Animal & Animal & Animal & Animal & Animal & Animal & Mean \pm SE \\
\hline ACh & 7.02 & 6.59 & 6.52 & 6.96 & 6.75 & 6.87 & $6.78 \pm 0.08$ \\
\hline
\end{tabular}




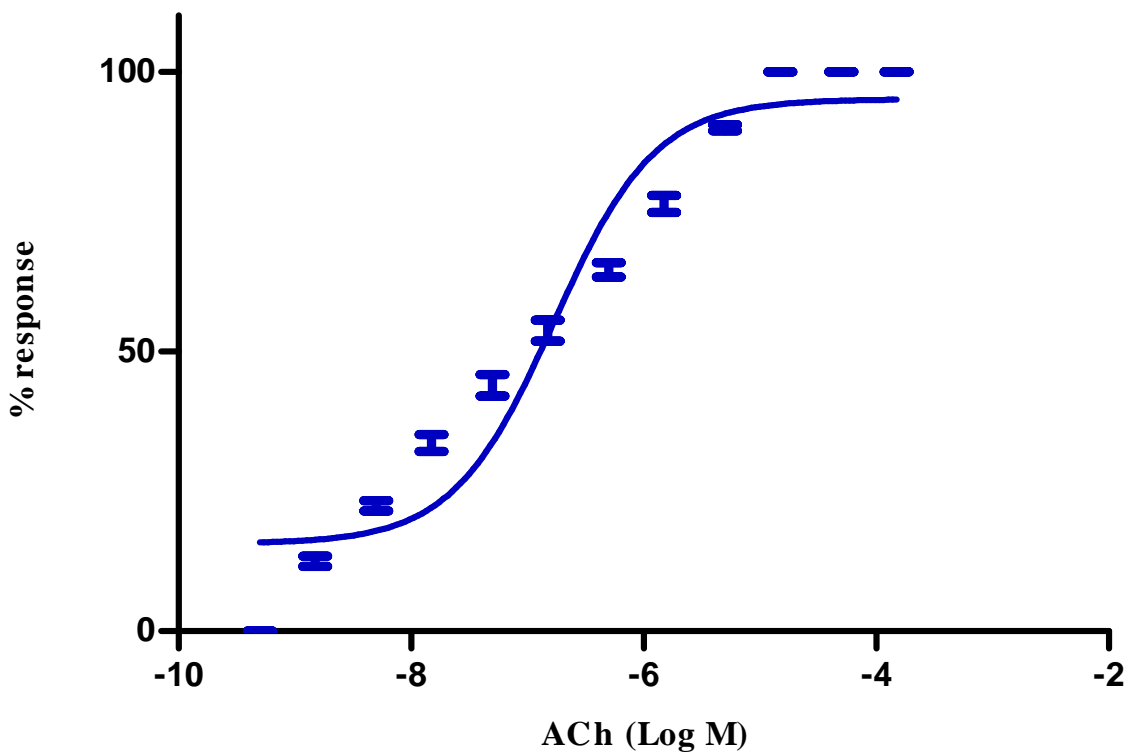

Figure 2 Graded dose response curve of ACh on ileum of Japanese quail

oesophageal muscularis mucosa for carbachol (Eglen \& Whiting, 1988). Kamikawa et al. (1985) reported the mean EC50 and pD2 values were $6.30 \times 10^{-14} \mathrm{M}$ and 13.2 for carbachol and $1.25 \times 10^{-8}$ $\mathrm{M}$ and 7.9 for $\mathrm{ACh}$ in longitudinal smooth muscle of guinea pig ileum. All these results indicate that muscarinic receptors are distributed with the same propensity in quails similar to that of other avian and mammalian species.

Muscarinic receptors are widely expressed in many tissues, from neuromuscular junctions, cardiovascular, respiratory and reproductive system to cortical regions of the brain involved in learning and memory (VanPatten \& Al-Abed, 2017). Muscarinic receptors play a significant role in maintaining gastrointestinal motility as well as its secretions (Alexander et al., 2017) .Besides, antibiotics like aminoglycosides and macrolides should not be given at higher doses for quails as they have inhibitory effect on gastrointestinal motility (Paradelis,1981). Better understanding of the receptor sub systems in the gastro intestinal tract of quail will help in the judicious selection of therapeutic agents for various ailments in commercial farming, since the gasto intestinal motility is the major determinant of the digestion and absorption of feed and thus modulate the feed conversion ratio of the quails. Hence any drug which can modulate the gastro-intestinal motility should be carefully administered in quails.

\section{Acknowledgement}

The author acknowledges the assistance from Indian Council of Agricultural Research (ICAR), New Delhi through post graduate scholarship (NTS). Financial supports from ICAR through research project (F No.7 (2)/-2011-EPD) andNational Bank for Agriculture and Rural Development G.O.(Rt)No.100/12/ AD RIDF XVI KERALA) are thankfully acknowledged.

\section{Conflicts of interest}

The authors declare that there are not any conflicts of interests

\section{References}

Alexander SP, Christopoulos A, Davenport AP, Kelly E, Marrion NV, Peters JA, Faccenda E, Harding SD, Pawson AJ, Sharman JL, Southan C (2017) The Concise Guide to Pharmacology 2017/18: $\mathrm{G}$ protein-coupled receptors. British Journal of Pharmacoogy 174: S17-S129.

Apu AS, Mondal A, Kitazawa T, Takemi S, Sakai T, Sakata I (2016) Molecular cloning of motilin and mechanism of motilininduced gastrointestinal motility in Japanese quail. General and Comparative Endocrinology 233: 53-62.

Bonner TI, Buckley NJ, Young AC, Brann MR (1987) Identification of a family of muscarinic acetylcholine receptor genes. Science 237: 527-532.

Dale HH (1914) The action of certain esters and ethers of choline, and their relation to muscarine. Journal of Pharmacology and Experimental Therapeutics 6: 147-190. 
Darroch S, Irving HR, Mitchelson FJ (2000) Characterisation of muscarinic receptor subtypes in avian smooth muscle. European Journal of Pharmacology 402: 161-169.

Delvalle NM, Fried DE, Rivera-Lopez G, Gaudette L, Gulbransen BD (2018) Cholinergic activation of enteric glia is a physiological mechanism that contributes to the regulation of gastrointestinal motility. American Journal of Physiology- Gastrointestinal and Liver Physiology 315: G473-G483.

Eglen RM, Whiting RL (1988) Comparison of the muscarinic receptors of the guinea-pig oesophageal muscularis mucosae and trachea in vitro. Journal of Autonomic Pharmacology 8:181-189.

Gholamnezhad Z, Ghorani V, Saadat S, Shakeri F, Boskabady MH (2018) The effects of medicinal plants on muscarinic receptors in various types of smooth muscle. Phytotherapy Research 32: 2340-2363.

Ghosh MN (2014) Fundamentals of Experimental Pharmacology $6^{\text {th }}$ Ed, Hilton and Co, P 142-143.
Kamikawa Y, Uchida K, Shimo Y(1985) Heterogeneity of muscarinic receptors in the guinea pig esophageal muscularis mucosae and ileal longitudinal muscle. Gastroenterology 88: 706-716.

Kitazawa T, Kondo N, Taneike T (2016) Pharmacological Characterization of muscarinic receptor subtypes involved in carbachol-induced contraction of the chicken proventriculus. Gastroenterology and Hepatology 2: 1003-1.

Loewi O (1921) Überhumoraleübertragbarkeit der Herznervenwirkung. PflügersArchiv European Journal of Physiology 189: 239-242.

Paradelis AG (1981) Aminoglycoside antibiotics and inhibition of the pendular movements of the intestine. Journal of Antimicrobial Chemotherapy $7: 109-110$.

VanPatten S, Al-Abed Y (2017) The challenges of modulating the 'rest and digest' system: acetylcholine receptors as drug targets. Drug Discovery Today 22: 97-104. 